\title{
EUROPA I CHRZEŚCIJAŃSTWO: HISTORIA I PRZYSZŁOŚĆ
}

\author{
EUROPE AND CHRISTIANITY: FROM YESTERDAY TO TOMORROW
}

Marios Begzos

Wydzial Teologiczny Uniwersytetu w Atenach, MBEgzos@Theol.uOA.gr

Słowa kluczowe: Chrześcijaństwo, Europa, tożsamość, dziedzictwo

Keywords: Christianity, Europe, identity, heritage

Czy Europa jest chrześcijańska? To pytanie kilka lat temu zdominowało dyskusję nad Europejską Konstytucją. Pojawiły się dwa różne, wywołujące spory, stanowiska, pierwsze, które dające pozytywną odpowiedź na to pytanie, drugie - negatywną. Ostateczny wynik był próbą zbagatelizowania całego zagadnienia poprzez ograniczenie konstytucyjnego zapisu i poprzez niebezpośrednie odniesienie do humanistycznego dziedzictwa Europy. To właśnie określenie zostało włączone do „Preambuły do Traktatu ustanawiającego Konstytucję dla Europy” - która wciąż nie została ratyfikowana.

Pytanie pozostaje jednak otwarte. Możliwa odpowiedź, oparta na historycznej sprawiedliwości, która mogłaby zostać zaakceptowana przez wszystkich, to twierdzenie, że tożsamość Europy jest biblijna, tj. monoteistyczna, bez jednoznacznego określenia chrześcijańska, czy wyłącznie humanistyczna bądź Oświeceniowa. To ostatnie uogólnienie skierowane jest w stronę agnostyków oraz ludzi antyreligijnych. Taka sugerowana powyżej odpowiedź powinna zostać uzupełniona o dwie negacje i jedną afirmację, które w związku z głównym tematem, wymagają dalszego wyjaśnienia.

\section{Chrześcijańska tożsamość Europy}

Chrześcijańska tożsamość Europy jest usprawiedliwiona historyczną obecnością wielu chrześcijańskich elementów oraz ich intelektualnego wpływu na przestrzeni wieków. Co więcej, powinniśmy zauważyć, iż początki Unii Europejskiej, zarówno w odniesieniu do tzw. EWG (Europejskiej Wspólnoty Gospodarczej) i wcześniejszej Europejskiej Wspólnoty Węgla i Stali, opierały się na chrześcijańskiej demokracji, co oznacza iż chrześcijański akcent nieustannie wpływał na ideę europejską. Zapomnienie o tych relacjach oznacza odcięcie się od zasad respektowanych przez prekursorów Unii Europejskiej. Nie ma potrzeby zatem, aby przywoływać kolejne przykłady dla potwierdzenia chrześcijańskiego rodowodu Europy.

Sprzeciw dla uznania chrześcijańskiej tożsamości Europy pochodzi właściwie z dwóch źródeł. Pierwszym jest europejskie dziedzictwo humanizmu epoki Renesansu i Oświecenia, drugim - niechrześcijańska tradycja religijna dwóch innych religii monoteistycznych, tj. Judaizmu i Islamu.

Dwa przeciwstawne stanowiska argumentują, że formalna konstytucyjna deklaracja o chrześcijańskiej tożsamości Europy doprowadzi do mylnych wniosków, a mianowicie jednostronnego wskazania na Europę stającą się zamkniętą „Ligą Chrześcijańską”, przy jednoczesnym ryzyku marginalizowania tych, którzy odeszli od Chrześcijaństwa: dysydentów, ateistów i wyznawców innych religii.

Dla odnalezienia prawdziwie wspólnego mianownika zjednoczonej Europy, chrześcijańska tożsamość nie jest uwzględniana, albowiem ocenia się ją częściej jako zagrożenie niż jako obietnicę. Ten sprzeciw wydaje się oczywiście słuszny, lecz jednocześnie powinien być skrytykowany jako nieumiarkowany. Przeciwnicy uznania chrześcijańskiej tożsamości Europy słusznie argumentują, iż rodzi ona ryzyko zamkniętej „Ligi Chrześcijańskiej”, gdzie z powodu jawnego elitaryzmu tożsamości chrześcijańskiej rzeczywiście tworzą się dwie dysproporcje: jedna w odniesieniu do przeszłości a druga, w odniesieniu do teraźniejszości.

Zapominamy, że przeszłość Europy w okresie średniowiecza, przed erą nowożytną, kształtowały Judaizm i Islam, mające wpływ na filozofię neoplatońską i arystotelesowską do takiego stopnia, iż rzymski katolicyzm za pośrednictwem scholastycyzmu (rozwijanego przez Tomasza z Akwinu), powiela muzułmańską koncepcję odnowienia teologii. Nikt nie może mówić o zjednoczonej 
Europie zapominając o wkładzie żydowskiej inteligencji, jak również o niektórych arabskich myślicielach, którzy wpłynęli na rozwój średniowiecznej teologii chrześcijańskiej.

Aby zachować historyczną sprawiedliwość w odniesieniu do przeszłości Europy, wraz ze wskazaniem chrześcijańskiego dziedzictwa, które oczywiście dominowało w procesie rozwoju Europy, lecz nigdy nie zmonopolizowało rozwoju europejskiej kultury, powinniśmy wspomnieć o dwóch pozostałych monoteistycznych tradycjach. Z pewnością, Chrześcijaństwo zachowało pierwszeństwo, lecz nigdy nie stanowiło wyłącznego faktora w diachronicznym procesie formowania europejskiej tożsamości.

Brak równowagi widoczny jest również we współczesnej historii Unii Europejskiej, gdzie dwie pozostałe religie monoteistyczne są pomijane, a Chrześcijaństwo ukazywane jako monopolizujące europejską tożsamość. W ten bowiem sposób marginalizowana jest obszerna i niezwykle ważna obecność imigrantów zarobkowych, wywodzących się głównie z krajów muzułmańskich. Islamscy imigranci, których miliony od dekad żyją w Europie, nie mogą czuć się jak w siebie w sytuacji, kiedy chrześcijańska tożsamość jest deklarowana jako wyłączna cecha Europy a nie jako jeden z priorytetowych parametrów?

Co więcej, powoli lecz systematycznie dyskryminacja dotyka europejskich Żydów, którzy wciąż żyją historyczną traumą Holokaustu, będącego dziełem Chrześcijan, lub dziejącego się za ich przyzwoleniem, należy jednak pamiętać o niekwestionowanym udziale wielu Chrześcijan z wszystkich kościołów i denominacji w ruchu oporu przeciwko totalitaryzmowi i tworzeniu obozów koncentracyjnych. Chrześcijańska tożsamość Europy wydaje się wykluczać każde inne religijne dziedzictwo, które jak w przypadku żydowskiego, przyczyniło się do integracji kultury europejskiej, zarówno w okresie średniowiecznej przeszłości, jak i w czasach współczesnych. Ostatni przykład uzasadnia historyczne roszczenia wszystkich wspomnianych religii do uznania ich udziału w budowaniu Europy.

Konstatacją nie jest jednak likwidacja chrześcijańskiej tożsamości Europy, ani monopolizacja wyłączności Chrześcijaństwa w procesie rozwoju Europy, lecz ukazanie prawdziwych priorytetów obecnych w tworzeniu Unii Europejskiej. Czy taki węzeł gordyjski mógłby zostać przecięty i czy mogłoby się pojawić jakieś salomonowe rozwiązanie? Wkrótce zaobserwujemy, że biblijna tożsamość Europy może stanowić odpowiedź na to pytanie i być jednocześnie rozwiązaniem wyżej postawionego problemu.

Zwolennicy humanizmu pragną całkowitego unicestwienia wszelkich odniesień do chrześcijańskiej tożsamości
Europy, albowiem przypomina ona tragedię wojen religijnych, które dręczyły Europę (Reformacja i Kontrreformacja), oraz współczesne spory religijne rozciągające się od północny kontynentu (Irlandia), aż po krańce południowe (Bałkany). Wspominanie o Chrześcijaństwie w tekście Konstytucji Europejskiej stanowi pożywkę dla pewnej fobii, tj. obawy, że stare spory religijne mogą ponownie odżyć. Z drugiej strony, tłumienie chrześcijańskich konotacji stymuluje humanistyczny wpływ Oświecenia, potwierdzając w praktyce zasady tolerancji, wyrozumiałości i wolności religijnej, nie tylko na poziomie krajowym, lecz również na ponadnarodowym poziomie Unii Europejskiej.

Sprzeciw zwolenników idei humanistycznej wobec chrześcijańskiej tożsamości Europy wydaje się zrozumiały, lecz musi zostać osądzony jako niepohamowany. Likwidacja Chrześcijaństwa będącego historycznym podmiotem nie pociąga za sobą jego unicestwienia w samej historii. Europa nie musi być nazwana chrześcijańską, lecz historycznie i intelektualnie jest nasycona biblijnym - monoteistycznym dziedzictwem, a samo Chrześcijaństwo stanowi wielką część tej biblijnej tradycji. „Zło” nie zostanie wykluczone poprzez magię, jaką jest zwalczane, lecz zostanie wyeliminowane w sposób drastyczny, taki jak zastąpienie „chrześcijańskiej tożsamości” „biblijną tożsamością”. Prowadzi nas to do odkrycia monoteistycznego dziedzictwa Europy, które omówimy w następnej części niniejszego wystąpienia.

\section{Monoteistyczna tożsamość Europy}

Po dwóch negacjach uwzględniających idee nie-chrześcijańskie i humanistyczne, możemy rozpocząć poszukiwania twierdzeń pozytywnych. Europejska tożsamość jest biblijna. Całe zagadnienie odnosi się do Biblii jako podstawy wiary w trzech wersjach monoteizmu w całym okresie historii Europy.

Monoteizm przypomina tryptyk - Judaizm, Chrześcijaństwo i Islam, który uznaje Abrahama jako patriarchę wiary i opiera się na Biblii. Te trzy wersje monoteizmu są zróżnicowane w odniesieniu do wielu istotnych punktów, ale łączy je wiara w Jednego i Jedynego Boga (monoteizm), który jest uważany za byt osobowy o męskich rysach i ojcowskich cechach. Ponadto, wszystkie te wersje monoteizmu opierają się na świętym tekście, tj. Biblii żydowskiej, Piśmie Świętym oraz Koranie, a każda z nich do pewnego stopnia traktuje pozostałe księgi jako uświęcone fundamentalne teksty o wierze, co można uznać za wspólną płaszczyznę tych trzech wersji monoteizmu.

Europa nie jest chrześcijańska lecz biblijna, czyli monoteistyczna. Nie jest wyłącznie chrześcijańska, albowiem zarówno Judaizm, jak i Islam, przyczyniały się do jej formowania w przeszłości i wciąż wpływają na 
jej rozwój. Dzieje się tak dzięki imigracji zarobkowej, lub działalności nie-chrześcijańskich obywateli Europy żyjących w niej od wieków. Chrześcijańska tożsamość Starego Kontynentu jest uznawana w kategorii historycznej i demograficznej, lecz w żadnym wypadku nie może zostać zaakceptowana jako wyłączna, czy tym bardziej jako nadrzędna. Chrześcijaństwo jest biblijne i w tym znaczeniu jest konstytuowane jako komponent Europy. Innymi słowy, to w „biblijności” tworzy się kryterium „chrześcijańskości” a nie odwrotnie.

To samo dotyczy dwóch pozostałych religii monoteistycznych, ponieważ i one mają wpływ na formowanie się Europy w takim stopniu, w jakim są one zakorzenione w Biblii, a dokładnie, w swoich własnych świętych tekstach i ich relacji do Biblii. Biblia Hebrajska jako Stary Testament stanowi część chrześcijańskiej Biblii, zaś Koran wyłącza „wierzących ludzi Biblii” (Chrześcijan i Żydów) z nakazu obowiązkowej islamizacji. Częściowa akceptacja Biblii zauważalna jest we wszystkich trzech religiach monoteistycznych i stanowi wystarczający i jednocześnie konieczny warunek, do objęcia ich w jedno monoteistyczne dziedzictwo, które przyczyniło się do formowania Europy.

Tłumienie biblijnej tożsamości Europy przez ideę humanizmu, byłoby fatalną pomyłką, albowiem wizja wolności jako zasadniczy postulat emancypacji Europy, zawarty jest w Biblii dzięki przykładom Wyjścia Narodu Wybranego z Egiptu (Exodus) i ideałowi ,przejścia” (Pesah, Wielkanoc) od niewoli ku wolności. Oświecenie może sekularyzować wolnościowe ideały Biblii, ale nie jest w stanie zaprzeczyć jej monoteistycznym korzeniom.

Odrzucenie przez zsekularyzowanych humanistów trzech religii monoteistycznych, powodowane jest tym, iż zapomniano o najważniejszych elementach tych religijnych tradycji, i pod pozorem emancypacji przeprowadzono atak, który odrzucił Boga Biblii jako Boga wolności, co przecież wyraźnie zostało określone już na początku Dekalogu.

Dzięki wspomnieniu biblijnych korzeni, wszelkie odniesienia do chrześcijańskiej tożsamości Europy będą dobrą okazją do wspierania wspomnianych idei wolnościowych oraz do ich wzmacniania w przyszłości, tak aby oświeceniowe ideały wolności były lepiej i skuteczniej popularyzowane. Wspomnienie o chrześcijańskiej tożsamości Europy wydaje się ledwie zauważalne, lecz odniesienie do jej biblijnej tożsamości jest wyraźne i ukazane w takim stopniu, który pozwala na inspirowanie naszych pobratymców obecnie i w przyszłości.

Koncepcja biblijnej tożsamości Europy satysfakcjonuje oczekiwania historycznej sprawiedliwości w odniesieniu do opisu rozwoju Europy, a z drugiej strony usprawiedliwia monoteistyczną rzeczywistość, która wspiera europejskie realia nie tylko w przeszłości, lecz również obecnie. W odniesieniu do przyszłości możemy wyraźnie dostrzec, że tożsamość biblijna obdarza Europę z niespodziewaną dynamiką i obiecuje wspólną przyszłość bardziej płodną i dynamiczną, niż bardziej odległe lub bliższe nam czasy minione.

Wspomnienie o biblijnej tożsamości Europy nikogo nie skrzywdzi. Przedstawiciele innych religii monoteistycznych i niereligijni humaniści mogą jedynie czerpać korzyści z deklaracji o biblijnej tożsamości Europy. W ten sposób wierzymy, że Europa jest na niej oparta oraz że tożsamość kryje w sobie łatwość i wolność niezbędną do głoszenia swej wiary w przyszłości, co staje się synonimem wolności i humanizmu człowieka.

Tłum. ks. dr Marek Ławreszuk 